\title{
Effect of nitrogen and application ways of a plant biostimulant on different wheat genotypes contrasting in stature
}

\author{
Adriana Queiroz de Almeida ${ }^{1 *}$, Peter Hedden ${ }^{2}$ and Rogério Peres Soratto ${ }^{1}$ \\ ${ }^{1}$ Department of Crop Science, Agricultural Sciences College, UNESP - Sao Paulo State University, Botucatu, \\ Sao Paulo, Brazil. \\ ${ }^{2}$ National Centre for Plant and Microbial Metabolomic, Crop Performance and Improvement Division, Rothamsted \\ Research Institute, Harpenden, United Kingdom.
}

Received 3 June, 2014; Accepted 25 July, 2014

\begin{abstract}
Wheat (Triticum aestivum L.) is the leading crops for human nutrition in Europe and in most temperate regions worldwide. This crop is demanding in nutrients, among them nitrogen $(\mathrm{N})$ is absorbed in higher amounts and its efficiency of utilization can be increased with a plant biostimulant use. The objective of this work was to evaluate the influence of different $\mathbf{N}$ levels and ways of biostimulant application on genotypes growth of wheat, tall and semi dwarf. The experiment was carried out, in 2010, at greenhouse located in Rothamsted Research Institute, Harpenden - United Kingdom. The design was in randomized blocks, with four replications. The experiment was a $3 \times 2 \times 2$ factorial arrangement consisting by three ways of application using a commercial biostimulant and two $\mathrm{N}$ levels provided by nutritive solution and two spring wheat genotypes (Green - tall and Red - semi dwarf). Isolated effect of biostimulant use was not observed on fresh matter and dry matter of aboveground part and root; however, $\mathrm{N}$ levels affected same variables, except root dry matter. A significant interaction between biostimulant and $\mathrm{N}$ was observed on dry matter of aboveground part. No significant results were found for length, surface, diameter and volume of root after biostimulant application and different $\mathrm{N}$ levels in Green and Red genotypes. Seed treatment and leaf spray with biostimulant did not promoted effects on $\mathbf{N}$ and $\mathrm{C}$ content in aboveground part and root for tall or dwarf wheat; on the other hand, significant differences were observed when $\mathbf{N}$ was applied through nutritive solution. Biostimulant application did not promoted increase on growth, $\mathrm{N}$ and $\mathrm{C}$ content of aboveground part, metabolites production and components of wheat production. Use of $\mathrm{N}$ promoted increase on fresh and dry matter of wheat, except dry matter of root, moreover, additions were observed in its content in aboveground part of wheat.
\end{abstract}

Key words: Semi dwarf, nutrients, plant regulator, root growth, content.

\section{INTRODUCTION}

Wheat (Triticum aestivum L.) is the leading crops for human nutrition in Europe and in most temperate regions worldwide (Costanzo and Bàrberi, 2014). This crop is demanding in nutrients, among them, nitrogen $(\mathrm{N})$ is

${ }^{*}$ Corresponding author. E-mail: adriana q_almeida@ya hoo.com.br, Tel: 00557581223858.

Author(s) agree that this artic le rema in perma nently open access under the terms of the Creative Commons Attribution License 4.0 Intemational Lic ense 
absorbed in higher amounts (Castro and Kluge, 1999; Sylvester-Bradley et al., 2001; Da Ros et al., 2003); moreover, it is composed of approximately $2.9 \% \mathrm{~N}$ in all plants and $2 \%$ in grains (Cantarella, 2007). Despite reports on assistance from Azospirillum genus in $\mathrm{N}$ absorption (Didonet et al., 1996; Dalla Santa et al., 2004), this crop needs to obtain almost all $\mathrm{N}$ from soil and fertilizers.

During the early stages, despite that wheat $\mathrm{N}$ demand is minor, fertilization is important to promote rapid initial development and to define production of this crop ( $\mathrm{Da}$ Ros et al., 2003), and also, $N$ is one of the nutrients that can influence yield and is the most absorbed in all cycles of wheat crop, resulting in high yield (Megda et al., 2009).

Growth and development of different crops are influenced by plant hormones, among them: auxin, cytokinin, gibberellin, ethylene and inhibitors. Combinations of these products have been evaluated and consequently a mixture of two or more plant regulators, or plant regulators with other substances (amino acids, nutrients and vitamins), can be called a plant stimulant or biostimulant, e.g., Stimulate ${ }^{\circledR}$ (Cato, 2006).

There are few papers explaining the wheat and the biostimulant Stimulate ${ }^{\circledR}$ relationship, but we know about plant hormone influence (auxin, gibberellin and cytokinin) in wheat metabolism and how much they can affect its growth and development (Castro and Kluge, 1999). Cato (2006) applied biostimulant between 3.5 and $5.0 \mathrm{ml} \mathrm{kg}$ of wheat seeds and observed increases in height, dry matter mass, tiller number and spike numbers per plant, moreover, crescent doses promoted linear growth in roots.

Reports about biostimulant effects on different crops are variable and divergent in relation to doses, methods of application, crop, environment and agricultural practices (Castro et al., 1998), as well as, doubts about how this biostimulant can modify growth of crops. Few analysis have been realized using this product associated with wheat crop and, there are doubts about how biostimulant application can promote efficiency of $\mathrm{N}$ use by crop, and more, if can increase growth, promote grain quality and consequently, the productivity.

This way, an evaluation about action of this product is an alternative to promote the understanding how biostimulant can act on wheat crop and also the possibility of initial growth improvement. Thus, the objective of this work was to evaluate the influence of different $\mathrm{N}$ levels and ways of biostimulant application on genotypes growth of wheat, tall and semi dwarf.

\section{MATERIALS AND METHODS}

The experiment was carried out in a greenhouse located in the Rothamsted Research Institute, Harpenden - United Kingdom in 2010. The design was in randomized blocks, with four replications. The experiment was a $3 \times 2 \times 2$ factorial arrangement con sisting by three ways of application using a commercial biostimulant (CT -
Control (without application), ST - $250 \mathrm{ml} \mathrm{ha}^{-1}$ seed treatment and $\mathrm{LT}-250 \mathrm{ml} \mathrm{ha}^{-1}$ leaf spray in floral initiation), two $\mathrm{N}$ levels (normal $10 \mathrm{mM}$ and low - $1 \mathrm{mM}$ ) provided by nutritive solution and two spring wheat genotypes (Green - tall and Red - semi dwarf). Commercial biostimulant (Stimulate ${ }^{\circledR}$ ) was used containing $0.009 \%$ of kinetin (cytokinin), $0.005 \%$ of gibberellic acid (gibberellin), $0.005 \%$ of indolebutyric acid (auxin) and $99.981 \%$ of inert ingredients (Castro, 1998).

Seeds were treated with biostimulant according company recommendation ( $4 \mathrm{ml} \mathrm{kg}^{-1}$ of seeds) and placed on petri dishes after 30 min to promote absorption of product. CT and LT received same volume of destilated water. Petri dishes were placed in a dark place, to promote germination. After three days, the transplant of four seeds was realized to the pots (with capacity of $4.0 \mathrm{~L}$ ) containing a wash sand + perlite mixture (50:50).

Spraying treatment was realized during leaf initiation (primary leaves). A hand sprayer with biostimulant solution was used for it and the solution contained $250 \mathrm{ml}^{-1}$ of biostimulant concentration. CT and ST received same content of distillate water.

Nutritive solution was supplied two days after emergence but nutritive stress (low $\mathrm{N}$ ) started after seven days. The nutritive solution of normal $\mathrm{N}$ contained, from stock solution, the following concentration for macronutrients: $236.15 \mathrm{~g} \mathrm{~L}^{-1}$ of $\mathrm{Ca}\left(\mathrm{NO}_{3}\right)_{2}, 101.11$ $\mathrm{g} \mathrm{L}^{-1}$ of $\mathrm{KNO}_{3}, 85.0 \mathrm{~g} \mathrm{~L}^{-1}$ of $\mathrm{NaNO}_{3}, 246.48 \mathrm{~g} \mathrm{~L}^{-1}$ of $\mathrm{MgSO}_{4} \times 7 \mathrm{H}_{2} \mathrm{O}$, $136.09 \mathrm{~g} \mathrm{~L}^{-1}$ of $\mathrm{KH}_{2} \mathrm{PO}_{4}$ and, $18.4 \mathrm{~g} \mathrm{~L}^{-1}$ of FeEDTA, and for micronutrients: $38.6 \mathrm{mg} \mathrm{L}^{-1}$ of $\mathrm{Cu}\left(\mathrm{NO}_{3}\right)_{2} .3 \mathrm{H}_{2} \mathrm{O}, 568.6 \mathrm{mg} \mathrm{L}^{-1}$ of $\mathrm{H}_{3} \mathrm{BO}_{3}, \quad 712.8 \mathrm{mg} \mathrm{L} \mathrm{L}^{-1}$ de $\mathrm{MnCl}_{2} .4 \mathrm{H}_{2} \mathrm{O}, 19.7 \mathrm{mg} \mathrm{L}^{-1}$ of $\left(\mathrm{NH}_{4}\right)_{6} \mathrm{Mo}_{7} \mathrm{O}_{24 .} 4 \mathrm{H}_{2} \mathrm{O}, 372 \mathrm{mg} \mathrm{L}^{-1}$ of $\mathrm{KCl}$ and $202.0 \mathrm{mg} \mathrm{L}^{-1}$ of $\mathrm{ZnCl}_{2} \cdot 7 \mathrm{H}_{2} \mathrm{O}$. And the solution of low $\mathrm{N}$ contained the following concentration for macronutrients: $111.10 \mathrm{~g} \mathrm{~L}^{-1}$ of $\mathrm{CaCl}_{2}, 101.90 \mathrm{~g} \mathrm{~L}^{-1}$ of $\mathrm{KNO}_{3}, 74.55 \mathrm{~g} \mathrm{~L}^{-1}$ of $\mathrm{KCl}, 58,40 \mathrm{~g} \mathrm{~L}^{-1}$ of $\mathrm{NaCl}, 120,30 \mathrm{~g} \mathrm{~L}^{-1}$ of $\mathrm{MgSO}_{4} .7 \mathrm{H}_{2} \mathrm{O}, 136.10 \mathrm{~g} \mathrm{~L}^{-1}$ of $\mathrm{KH}_{2} \mathrm{PO}_{4}$ and, $18.35 \mathrm{~g} \mathrm{~L}^{-1}$ of FeEDTA, and micronutrients: $38.6 \mathrm{mg} \mathrm{L}^{-1}$ of $\mathrm{CuCl}_{2} .2 \mathrm{H}_{2} \mathrm{O}, 568.6 \mathrm{mg} \mathrm{L}^{-1}$ of $\mathrm{H}_{3} \mathrm{BO}_{3}, 712.8 \mathrm{mg} \mathrm{L}^{-1}$ de $\mathrm{MnCl}_{2} .4 \mathrm{H}_{2} \mathrm{O}, 3.5 \mathrm{mg} \mathrm{L}^{-1}$ of $\mathrm{NaMoO}_{4} .2 \mathrm{H}_{2} \mathrm{O}$, $372 \mathrm{mg} \mathrm{L}^{-1}$ of $\mathrm{KCl}$ and $202.0 \mathrm{mg} \mathrm{L}^{-1}$ of $\mathrm{ZnCl}_{2} .7 \mathrm{H}_{2} \mathrm{O}$.

After spraying, water supply, or nutritive solution, was applied only the following day to promote better absorption and avoid washing away the product. Only distilled water was supplied and according to crop needs. During experiments, temperature in the glasshouse was regulated at 14 and $18^{\circ} \mathrm{C}$ for day and night, respectively.

Day length was regulated for $16 \mathrm{~h}$ and started at $5 \mathrm{am}$. Temperature was monitored each twenty seconds and lights were switched off automatically. At 39 days after emergence, in the floral initiation, the experiment was finalized. According to Sangoi et al. (2007) this phase determines the mass and number of grain and ear size, e.g., they are related with cultural treats realized until flowering. Fresh matter and dry matter of above ground part, root system evaluation, fresh matter and dry matter of root and, $\mathrm{N}$ and carbon (C) content in aboveground part and root were realized.

The aboveground part was collected and weighed to determine fresh matter mass. After was dried in an oven at $80^{\circ} \mathrm{C}$ for $72 \mathrm{~h}$ for dry matter mass determination (g per plant). Roots were separated from substrate through washing with tap sterile water on the sieve with a mesh of $0.5 \mathrm{~mm}$. The washed material were packed in a universal collector containing $30 \%$ alcohol $+70 \%$ water solution, after were maintained in a stored room at $4^{\circ} \mathrm{C}$ until evaluation. Root evaluation was realized according to Tennant (1975) in a specific scanner coupled with a computer provided with WinRhyzo Arabdopsis 2008 software. Length (m per plant), surface $\left(\mathrm{mm}^{2}\right.$ per plant), diameter $(\mathrm{mm})$ and volume $\left(\mathrm{mm}^{3}\right)$ were evaluated. After were dried in an oven at $80^{\circ} \mathrm{C}$ for $72 \mathrm{~h}$ for dry matter mass determination (g per plant).

The material used to determine dry matter mass (aboveground part and root) was grounded in a ball mill (Glen Creston Equipments) and $\mathrm{N}$ and $\mathrm{C}$ analysis followed principles of LECO Truspec Combustion Analyser (LECO Corporation) based on modified digestion method of Dumas (AOAC, 2000). The results 
Table 1. Fresh and dry matter of aboveground part and root of wheat genotypes as a function of different $\mathrm{N}$ levels in nutritive solution and biostimulant application on seeds and leaf spray.

\begin{tabular}{|c|c|c|c|c|}
\hline Treatment & $\begin{array}{l}\text { Fresh matter of } \\
\text { aboveground part } \\
\text { (g per plant) }\end{array}$ & $\begin{array}{c}\text { Dry matter of } \\
\text { aboveground part } \\
\text { (g per plant) }\end{array}$ & $\begin{array}{l}\text { Fresh matter of root } \\
\quad \text { (g per plant) }\end{array}$ & $\begin{array}{l}\text { Dry matter of root } \\
\text { (g per plant) }\end{array}$ \\
\hline \multicolumn{5}{|c|}{ biostimulant } \\
\hline Control & $6.50^{\mathrm{a}}$ & $1.05^{\mathrm{a}}$ & $5.14^{\mathrm{a}}$ & $0.22^{\mathrm{a}}$ \\
\hline ST & $6.83^{\mathrm{a}}$ & $1.05^{\mathrm{a}}$ & $4.53^{\mathrm{a}}$ & $0.18^{\mathrm{a}}$ \\
\hline LT & $6.13^{\mathrm{a}}$ & $0.92^{\mathrm{a}}$ & $4.68^{\mathrm{a}}$ & $0.22^{\mathrm{a}}$ \\
\hline \multicolumn{5}{|c|}{$\mathrm{N}$ in solution (mM) } \\
\hline 1 & $3.62 b$ & $0.66 \mathrm{~b}$ & $3.79 b$ & $0.22^{\mathrm{a}}$ \\
\hline 10 & $9.36^{\mathrm{a}}$ & $1.36^{\mathrm{a}}$ & $5.78^{\mathrm{a}}$ & $0.20^{a}$ \\
\hline \multicolumn{5}{|l|}{ Genotype } \\
\hline Green & $6.89^{\mathrm{a}}$ & $1.13^{\mathrm{a}}$ & $4.87^{\mathrm{a}}$ & $0.22^{\mathrm{a}}$ \\
\hline Red & $6.08^{a}$ & $0.89 b$ & $4.70^{\mathrm{a}}$ & $0.19^{\mathrm{a}}$ \\
\hline \multicolumn{5}{|c|}{ Interactions } \\
\hline$B \times N$ & ns & * & ns & ns \\
\hline$B \times G$ & ns & ns & ns & ns \\
\hline $\mathrm{G} \times \mathrm{N}$ & ns & ns & ns & * \\
\hline$B \times G \times N$ & ns & ns & ns & ns \\
\hline
\end{tabular}

Means followed by same letter in the column, within each factor, do not differ significantly by Tukey test at $5 \%$ of probability. ns, * and ** are not significant, significant at $p<0.05$ and $p<0.01$ by $F$ test, respectively. Treatments were: Control (without biostimulant application), ST (seed treatment), LT (leaf spray treatment during floral initiation). Genotypes were Green (tall) and Red (semi dwarf). Interactions were BxN (biostimulant $x$ nitrogen), GxN (genotype $x$ nitrogen), BxGxN (biostimulant $x$ genotype $x$ nitrogen).

were submitted to analysis of variance (ANOVA) and Tukey test was use to compare means at $5 \%$ of probability.

\section{RESULTS}

Isolated effect of biostimulant use was not observed on fresh matter and dry matter of aboveground part and root (Table 1). However, $\mathrm{N}$ levels affected same variables (fresh matter of aboveground part and root, except root dry matter), and in the normal level of $\mathrm{N}(10 \mathrm{mM})$ could be observed increasing from 158.6, 106.1 and $52.5 \%$ for fresh matter and dry matter of aboveground part and fresh matter of root, respectively. For different genotypes evaluated, only for dry matter mass of aboveground part were found significant results, and for semi dwarf wheat was found lower mean (Table 1).

A significant interaction between biostimulant and $\mathrm{N}$ was observed on dry matter of aboveground part (Table 1). After unfolding, higher dry matter of plants was observed when higher amounts of $\mathrm{N}$ were supplied (Table 2). Biostimulant treatments promoted decreasing on dry matter of aboveground part when normal $\mathrm{N}$ level was supplied through nutritive solution (10 mM).

According to Table 3, there was a decreasing of $27.3 \%$ on dry matter of root, semi dwarf wheat, when applied normal $\mathrm{N}$ level $(10 \mathrm{mM})$ and higher means were found for tall wheat (Green). No significant results were found for length, surface, diameter and volume of root after biostimulant application and different $\mathrm{N}$ levels in Green and Red genotypes, tall and semi dwarf, respectively; as well as interactions (Table 4).

Seed treatment and leaf spray with biostimulant did not promoted effects on $\mathrm{N}$ and $\mathrm{C}$ content in aboveground part and root for tall or dwarf wheat. On the other hand, significant differences were observed on $\mathrm{N}$ content (above ground and root) when $\mathrm{N}$ was applied through nutritive solution, it also was observed in $\mathrm{C}$ content in the root (Table 5). The interaction genotype $\times \mathrm{N}$ was significant for $\mathrm{N}$ content in aboveground part (Table 5), and, after unfolding, increasing was observed both in Green as in Red, tall and semi dwarf wheat, respectively, when applied $10 \mathrm{mM}$ of $\mathrm{N}$ (Table 6). In the higher $\mathrm{N}$ level, Red wheat presented higher $\mathrm{N}$ content in the aboveground part.

\section{DISCUSSION}

Even if effects of biostimulant use were not observed on fresh and dry matter of aboveground part and root, it is known that wheat plants demand high amount of macronutrients, mainly $\mathrm{N}$ and potassium, and more, the most studies about $\mathrm{N}$ and wheat deal only with one 
Table 2. Dry matter of aboveground part of wheat genotypes as a function of different $\mathrm{N}$ levels in nutritive solution and biostimulant application on seeds and leaf spray. Mean of two genotypes.

\begin{tabular}{lccc}
\hline & \multicolumn{3}{c}{ Biostimulant } \\
\cline { 2 - 4 } N levels & Control & ST & LT \\
\cline { 2 - 4 } & & Dry matter of aboveground part & $0.67^{\mathrm{aB}}$ \\
\cline { 2 - 4 } 1 & $0.62^{\mathrm{aB}}$ & $0.70^{\mathrm{aB}}$ & $1.19^{\mathrm{bA}}$ \\
\hline
\end{tabular}

Means followed by same letter in the column, within each factor, do not differ significantly by Tukey test at $5 \%$ of probability. Treatments were: Control (without biostimulant application), ST (seed treatment), LT (leaf spray treatment during floral initiation).

Table 3. Dry matter of root of wheat genotypes as a function of $\mathrm{N}$ levels in nutritive solution. Mean of two genotypes.

\begin{tabular}{|c|c|c|}
\hline \multirow{3}{*}{ N Doses } & \multicolumn{2}{|c|}{ Genotypes } \\
\hline & Green & Red \\
\hline & \multicolumn{2}{|c|}{ Dry matter of root (g per plant) } \\
\hline 1 & $0.21^{\mathrm{aA}}$ & $0.22^{\mathrm{aA}}$ \\
\hline 10 & $0.24^{\mathrm{aA}}$ & $0.16^{\mathrm{bA}}$ \\
\hline
\end{tabular}

Means followed by same letter in the column, within each factor, do not differ significantly by Tukey test at $5 \%$ of probability.

Table 4. Length, surface, diameter and volume of root of wheat genotypes as a function of different $\mathrm{N}$ levels and biostimulant application on seed and leaf spray.

\begin{tabular}{|c|c|c|c|c|}
\hline Treatment & $\begin{array}{l}\text { Root Length } \\
\text { (m per plant) }\end{array}$ & $\begin{array}{l}\text { Root surface } \\
\text { ( } \mathrm{mm}^{2} \text { per plant) }\end{array}$ & $\begin{array}{l}\text { Root diameter } \\
(\mathrm{mm})\end{array}$ & $\begin{array}{c}\text { Root volume } \\
\left.\text { ( } \mathrm{mm}^{3} \text { per plant }\right)\end{array}$ \\
\hline \multicolumn{5}{|c|}{ Biostimulant } \\
\hline Control & $0.598^{\mathrm{a}}$ & $644^{\mathrm{a}}$ & $0.024^{\mathrm{a}}$ & $54^{\mathrm{a}}$ \\
\hline ST & $0.565^{\mathrm{a}}$ & $627^{\mathrm{a}}$ & $0.021^{\mathrm{a}}$ & $54^{\mathrm{a}}$ \\
\hline LT & $0.654^{\mathrm{a}}$ & $706^{a}$ & $0.022^{\mathrm{a}}$ & $59^{a}$ \\
\hline \multicolumn{5}{|c|}{$\mathrm{N}$ in solution $(\mathrm{mM})$} \\
\hline 1 & $0.602^{\mathrm{a}}$ & $652^{\mathrm{a}}$ & $0.021^{a}$ & $55^{a}$ \\
\hline 10 & $0.603^{a}$ & $667^{\mathrm{a}}$ & $0.023^{a}$ & $57^{\mathrm{a}}$ \\
\hline \multicolumn{5}{|l|}{ Genotype } \\
\hline Green & $0.590^{\mathrm{a}}$ & $648^{\mathrm{a}}$ & $0.022^{\mathrm{a}}$ & $54^{\mathrm{a}}$ \\
\hline Red & $0.616^{\mathrm{a}}$ & $671^{a}$ & $0.022^{\mathrm{a}}$ & $57^{\mathrm{a}}$ \\
\hline \multicolumn{5}{|c|}{ Interactions } \\
\hline$B \times N$ & ns & ns & ns & ns \\
\hline$B \times G$ & ns & ns & ns & ns \\
\hline $\mathrm{G} \times \mathrm{N}$ & ns & ns & ns & ns \\
\hline $\mathrm{B} \times \mathrm{G} \times \mathrm{N}$ & $\mathrm{ns}$ & ns & $\mathrm{ns}$ & ns \\
\hline
\end{tabular}

Means followed by same letter in the column, within each factor, do not differ significantly by Tukey test at $5 \%$ of probability. ns, * and ${ }^{* *}$ are not significant, significant at $p<0.05$ and $p<0.01$ by $F$ test, respectively. Treatments were: Control (without biostimulant application), ST (seed treatment), LT (leaf spray treatment during floral initiation). Genotypes were Green (tall) and Red (semi dwarf). Interactions were BxN (biostimulant x nitrogen), GxN (genotype x nitrogen), BxGxN (biostimulant x genotype $x$ nitrogen).

cultivar, this way is difficult to get new information about different genotypes, which respond in different ways when $\mathrm{N}$ is applied, because they have a different genetic basis (Viana and Kiehl, 2010; Sangoi et al., 2007). 
Table 5. Nitrogen and carbon content of aboveground part and root as a function of different $\mathrm{N}$ levels and biostimulant application on seed and leaf spray treatment.

\begin{tabular}{|c|c|c|c|c|}
\hline Treatment & $\begin{array}{c}\begin{array}{c}N \text { aboveground part } \\
(\mathrm{g} / \mathrm{kg})\end{array} \\
\end{array}$ & $\begin{array}{c}\begin{array}{c}C \text { aboveground part } \\
(\mathrm{g} / \mathrm{kg})\end{array} \\
\end{array}$ & $\begin{array}{l}N \text { root } \\
(\mathrm{g} / \mathrm{kg})\end{array}$ & $\begin{array}{l}\text { C root } \\
(\mathrm{g} / \mathrm{kg})\end{array}$ \\
\hline \multicolumn{5}{|c|}{ Biostimulant } \\
\hline Control & $24.7^{\mathrm{a}}$ & $396.1^{\mathrm{a}}$ & $12.6^{\mathrm{a}}$ & $400.6^{a}$ \\
\hline ST & $26.7^{\mathrm{a}}$ & $421.5^{\mathrm{a}}$ & $11.9^{\mathrm{a}}$ & $399.4^{\mathrm{a}}$ \\
\hline LT & $26.9^{\mathrm{a}}$ & $420.3^{a}$ & $12.9^{\mathrm{a}}$ & $398.1^{a}$ \\
\hline \multicolumn{5}{|c|}{$\mathrm{N}$ in solution (mM) } \\
\hline 1 & $13.1^{\mathrm{b}}$ & $424.3^{\mathrm{a}}$ & $8.8^{\mathrm{b}}$ & $37.2^{\mathrm{b}}$ \\
\hline 10 & $39.1^{\mathrm{a}}$ & $401.0^{\mathrm{a}}$ & $16.1^{\mathrm{a}}$ & $42.7^{\mathrm{a}}$ \\
\hline \multicolumn{5}{|l|}{ Genotype } \\
\hline Green & $23.9 \mathrm{~b}$ & $405.1^{\mathrm{a}}$ & $11.9^{\mathrm{a}}$ & $366.9^{a}$ \\
\hline Red & $28.4^{\mathrm{a}}$ & $4202^{a}$ & $13.0^{\mathrm{a}}$ & $401.9^{a}$ \\
\hline \multicolumn{5}{|c|}{ Interactions } \\
\hline $\mathrm{B} \times \mathrm{N}$ & ns & ns & ns & ns \\
\hline$B \times G$ & ns & ns & ns & ns \\
\hline $\mathrm{G} \times \mathrm{N}$ & * & ns & ns & ns \\
\hline $\mathrm{B} \times \mathrm{G} \times \mathrm{N}$ & ns & ns & ns & ns \\
\hline
\end{tabular}

Results statistically significant were not found for other variables and lower means were found for Red cultivar (semi dwarf wheat). According to Hedden (2003) in many species, gibberellin concentration can restrict growth plant, because it has an important role on regulation of development processes, which are critical to agriculture. Data presented in this manuscript agree with Miralles et al. (1997), they suggest that lower values on biomass of aboveground part are positively correlated with root growth and vice versa. Waines and Ehdaie (2007) evaluating genotypes from Iran, China, Japan, California, Iraq, Pakistan and Europe (tall and semi dwarf, glasshouse and field experiments) observed significant differences among their production of root biomass and they associated grain production with increasing of this variable. The same authors reported that there are few studies about root system and many times they are not considered important despite root increase water and $\mathrm{N}$ absorption and, to reduce environmental pollution, consequently.

Results about decreasing on dry matter of root, semi dwarf wheat, and increasing of tall wheat disagree with Camargo (1974) which one since 70' observed different behaviour between tall and semi dwarf wheat. The same author observed that dwarf and semi dwarf wheat presented stability and the best reaction when higher $\mathrm{N}$ doses were applied (for example $150 \mathrm{~kg} \mathrm{ha}^{-1}$ ) unlike tall wheat, that had increase in its production until $50 \mathrm{~kg} \mathrm{ha}^{-1}$; he concluded that, in conditions of higher $\mathrm{N}$ fertilization, semi dwarf wheat can benefit better than tall wheat. Coelho et al. (1998) evaluated 'Embrapa-22' cultivar and four $\mathrm{N}$ doses (monocrop and intercrop with maize) and they observed increase on dry matter until $94 \mathrm{~kg} \mathrm{ha}^{-1}$. Marschner (1995) explain that in cereals, $\mathrm{N}$ doses can increase phytohormones and compounds that can promote growth and development, thus, in the present study, the application of this nutrient may have influenced on metabolism of genotypes evaluated.

No significant results for length, surface, diameter and volume of root after biostimulant application and different $N$ levels in Green and Red genotypes, and their interactions, disagree with Subbiah et al. (1968), they reported that semi dwarf wheat presented smaller root system when compared with tall one, during field experiment. Siddique et al. (1990) reported about values of dry matter of root; semi dwarf wheat presented lowest values resulting, according to this author, in a low root:aboveground part ratio. Wojciechowski et al. (2009) reported that $R$ ht allele effect are unclear and results in different growth conditions are contradictory. The same authors obtained inconclusive results and explain that can be due to different genetic antecedents were responsible to produce actual wheat plants; they still report that semi dwarf plants have smaller root system 
because can reduce investment on dry matter root production or different growth conditions, or all factors cited. In their experiment with different wheat genotypes, tall and semi dwarf, these authors observed no differences on root length among cultivars with dwarfism allele and control, as well as diameter root.

Significant differences observed when $\mathrm{N}$ was applied through nutritive solution, agree with results from Teixeira -Filho et al. (2007), in a field experiment and sprinkler system, observed an increase on foliar $\mathrm{N}$ content when applied this nutrient until the dose of $77 \mathrm{~kg} \mathrm{ha}^{-1}$. Viana and Kiehl (2010) did not find significant results for $\mathrm{N}$ accumulation of aboveground part when evaluated 'IAC 370' cultivar during experiment carried out in a greenhouse and applied five doses of $\mathrm{N}$. Between genotypes evaluated, significant differences were observed in the $\mathrm{N}$ content of aboveground part and in dwarf wheat was observed the highest mean and it was $18.9 \%$ higher than that observed in tall wheat. SylvesterBradley and Kindred (2009) evaluating efficiency of $\mathrm{N}$ use and harvest index of this nutrient, explain that there are few data available about $\mathrm{N}$ use in cereals different genetically, however it is known that since the introduction of semi dwarf plants, these values have been modified. Pearman et al. (1978) applied eight $\mathrm{N}$ doses in wheat plants, tall and semi dwarf, and observed that in plants with dwarfism gene, higher $\mathrm{N}$ doses promoted decrease in the variables evaluated, when compared with tall plants.

\section{Conclusion}

Biostimulant application did not promoted increase on growth, $\mathrm{N}$ and $\mathrm{C}$ content of above ground part. Use of $\mathrm{N}$ promoted increase on fresh and dry matter of wheat, except dry matter of root, moreover, additions were observed in its content in above ground part of wheat.

\section{Conflict of Interest}

The authors have not declared any conflict of interest.

\section{ACKNOWLEDGMENTS}

To Fundação de Amparo à Pesquisa do Estado de São Paulo (FAPESP), Rothamsted Research Institute and Stoller do Brasil.

\section{REFERENCES}

AOAC (Association of Official Analytical Chemists) (2000). Official Methods of Analysis. Gaithersburg: Association of Official Analytical Chemists.

Cantarella H (2007). Nitrogênio. In: Fertilidade do solo. (Eds R. F. Novais, V. H. Alvarez, N. F. Barros, R. L. F. Fontes, R. B. Cantarutti,
J. C. L. Neves), Viçosa: Sociedade Brasileira de Ciência do Solo. pp. 234-392.

Cato SC (2006). Ação de bioestimulante nas culturas do amendoinzeiro, sorgo e trigo e interações entre auxinas, citocininas e giberelinas. PhD thesis, Universidade de São Paulo, Piracicaba, São Paulo.

Camargo PCE de O (1974). Comportamento de cultivares de trigo em solos de várzea do Estado de São Paulo. Bragantia 33:65-73. http://dx.doi.org/10.1590/S0006-87051974000100007 http://dx.doi.org/10.1590/S0006-87051974000100007 http://dx.doi.org/10.1590/S0006-87051974000100007

Castro PRC (1998). Utilização de reguladores vegetais na fruticultura, na horticultura e em plantas ornamentais. Piracicaba: ESALQ/DIBD.

Castro PRC, Kluge RA (1999). Ecofisiologia de cultivos anuais: trigo, milho, soja, arroz e mandioca. São Paulo: Nobel.

Coelho FC, Vieira C, Mosquim PR, Cassini STA (1998). Nitrogênio e molibdênio nas culturas do milho e do feijão, em monocultivos e em consórcio: I - Efeitos sobre o feijão. Revista Ceres 260:393-407.

Da Ros CO, Salet RL, Porn RL, Machado JNC (2003). Disponibilidade de nitrogênio e produtividade de milho e trigo com diferentes métodos de adubação nitrogenada no sistema de plantio direto. Ciência Rural, 33:799804.http://www.scielo.br/pdf/cr/v33n5/17122.pdf http://dx.doi.org/10.1590/S0103-84782003000500002

Dalla Santa OR, Hérnandez F, Alvarez GLM, Ronzelli Junior P, Soccol CR (2004). Azospirillum sp. inoculation in wheat, barley and oats seeds greenhouse experiments. Brazilian Arch. Biol. Technol. 47:843-850.http://dx.doi.org/10.1590/S1516-89132004000600002 http://dx.doi.org/10.1590/S1516-89132004000600002

Didonet AD, Lima O dos S, Candaten AA, Rodrigues O (2000). Realocação de nitrogênio e de biomassa para os grãos, em trigo submetido à inoculação de Azospirillum. Pesquisa Agropecuária Brasileira 35:401-411.http://www.scielo.br/pdf/pab/v35n2/6886.pdf http://dx.doi.org/10.1590/S0100-204X2000000200019 http://dx.doi.org/10.1590/S1413-70542009000400016

Pearman I, Thomas SM, Thorne GN (1978). Effect of nitrogen fertilizer on growth and yield of semi-dwarf and tall varieties of winter wheat. J. Agric. Sci. 91:31-45.DOI:10.1017/S0021859600056604 http://dx.doi.org/10.1017/S0021859600056604

Sangoi L, Berns AC, Almeida ML de, Zanin CG, Schweitzer C (2007). Características agronômicas de cultivares de trigo em resposta à época da adubação nitrogenada de cobertura. Ciência Rural 37:1564-1570. http://dx.doi.org/10.1590/S0103-84782007000600010 http://dx.doi.org/10.1590/S0103-84782007000600010

Subbiah BV, Katyal JC, Narasimham RL, Dakshinamurti C (1968). Preliminary investigations on root distribution of high yielding wheat varieties. Int. J. Appl. Radiation and Isotopes 19:385-390. DOI:10.1016/0020-708X(68)90183-X http://dx.doi.org/10.1016/0020708X(68)90183-X

Sylvester-Bradley R, Stokes DT, Scott K (2001). Dynamics of nitrogen capture without fertilizer: the baseline for fertilizing winter wheat in the UK. J. Agric. Sci. 136:15-33. http://dx.doi.org/10.1017/S0021859600008479

Teixeira FMCM, Buzetti S, Alvarez R de CF, Freitas JG de, Arf O, Sá ME de (2007). Resposta de cultivares de trigo irrigados por aspersão ao nitrogênio em cobertura na região do Cerrado. Acta Scientiarum.Agronomy 29:421-425. DOI: 10.4025/actasciagron.v29i3.471 http://dx.doi.org/10.4025/actasciagron.v29i3.471 10.1093/aob/mcm180.http://dx.doi.org/10.1093/aob/mcm180

Wojciechowski T, Gooding MJ, Ramsay L, Gregory PJ (2009). The effects of dwarfing genes on seedling root growth of wheat. J. Exper. Bot. 60:2565-2573. DOI: 10.1093/jxb/erp107. http://dx.doi.org/10.1093/jxb/erp107 